\title{
Chloroplast DNA
}

National Cancer Institute

\section{Source}

National Cancer Institute. Chloroplast DNA. NCI Thesaurus. Code C111158.

The DNA that is located in the photosynthetic, chlorophyll-containing org anelle in the cells of young leaves and stems of higher plants. 